DOI 10.18551/rjoas.2020-03.05

\title{
THE GROWTH AND YIELD OF COFFEE ARABICA IN SHADE CONDITIONS ON DIFFERENT TREATMENT OF PRUNING AND FERTILIZING
}

\author{
Siahaan Adriani S.A. ${ }^{*}$, Doctoral Student in Agricultural Science \\ Harahap Erwin Masrul, Hanum Chairani \\ University of Sumatera Utara, Medan, Indonesia \\ Karim Abubakar \\ Department of Soil Science, Syiah Kuala University, Banda Aceh, Indonesia \\ *E-mail: adriani.siahaan11@gmail.com
}

\begin{abstract}
Coffee plants are C3 plant groups, with characteristic of low photosynthetic efficiency, which is due to the occurrence of photorespiration. In simple agroforestry systems, legumes are commonly used as shade trees. In addition, pruning and fertilizing are also very important cultivation techniques in coffee plantation business. This study was aimed to to obtain the maximum potential of coffee production at a certain height in Humbahas Regency with a package treatment of pruning, fertilizing and shade technology. Plant experiments were carried out at an elevation zone of 1300-1400 meters above sea level (m asl) which was designed in the form of Splits plot design. There are three factors tested, the main plot is shade with a level of non-shading (N0) and shading (N1); the main subplots are pruning, namely pruning with the farmer system (P1) and pruning recommendations (P2); while the subplots are fertilization methods consisting of: farmers' fertilizing level (O0), giving organic fertilizer from coffee pulp at a level of $10 \mathrm{~kg} /$ tree (O1), giving organic fertilizer from manure at a level of $10 \mathrm{~kg} /$ tree (O2), giving phosphate fertilizer (SP36) $150 \mathrm{~g} /$ tree. The shading as the main plot only gives a significant effect on dry weight parameters of the seeds. However, the interaction effect which is known to given significant effect is the Shading-PruningFertilization, which produces a real effect on all parameters. In the zone of elevation zones $1300-1400 \mathrm{~m}$ asl the combination of shading, pruned recommended and $10 \mathrm{~kg} /$ tree manure (N1P2O2) is the best treatment.
\end{abstract}

\section{KEY WORDS}

Growth, production, coffee, shading, pruning, fertilization.

Coffee plants (Coffea sp.) are C3 plants, with low photosynthetic efficiency characteristic, because the photorespiration occurs. However, the low photosynthetic efficiency makes the growth rate of coffee plants themselves not optimal (Mawardi, 2008). Coffee is grown in mixed systems (agroforestry), ranging from simple to complex mixed systems that resemble forests (Hairiah \& Rahayu, 2010). Coffee gardens can be cultivated through farming systems that lead to agroforestry (Dariah et al., 2005). In simple agroforestry systems, the common shade is legume trees such as dadap (Erythrina sububrams), gamal (Gliricidia sepium), and lamtoro (Leucaena glauca) which are useful for feed and as soil fertilizers, so that the use of chemical fertilizers decreases (Hairiah \& Rahayu, 2010). However, there are several shade-free coffee cultivations such as in Hawaii, Brazil and Kenya (Prawoto et al., 2006; Panggabean, 2011).

Pruning is one of the most important cultivation techniques business of coffee planting, because pruning is related to the supply of fruit branches which are the main organ producing in coffee fruit. The production of coffee plants is largely determined by the number of productive fruit branches during a conception season. Irregular and narrow spacing causes crop canopies to overlap with plant aging, therefore, pruning is an effective solution to reduce the effects of excessive initial constriction on the plantation. Pruning is a 
technology that has been associated with higher yields due to the promotion of reproductive output in different plant species (Bilir et al., 2006; Dutkuner et al., 2008).

Coffee plants are best cultivated at soil conditions with high organic matter content, because the productivity of coffee plants is directly related to the level of organic matter in the soil. The optimal level of organic ingredients for coffee plants ranges from $2-5 \%$, depending on the soil texture class. Organic matter plays an important role in plant productivity because of its influence on the physiological, chemical and biological characteristics of the soil. In this case it is also related to soil air, supports water infiltration, reduces erosion and activates the life of soil organisms (Wintgens, 2012). In addition, organic matter also greatly increases cation exchange capacity (CEC) in tropical soils. Organic materials also help to resist acidity caused by certain nitrogen fertilizers. This is very important because high acidity levels in the soil reduce microbial activity, and further develop toxicity caused by the presence of aluminum and manganese.

Coffee is an important commodity in Indonesia as an agent of development that provides income, jobs for 2.3 million farmers, the formation of growth centers, encouraging coffee agribusiness and agro-industry (GAEKI ICEA, 2015; ICO, 2009; Marsh, 2005; RoldánPérez et al., 2009). In 2010, Indonesia became the third major coffee producer in the world after Brazil and Vietnam, while in fourth place was Colombia. These four countries produce $63.48 \%$ of world coffee production (ICO, 2014). At the national level, North Sumatra Province is in fourth place in the total production of arabica and robusta coffee, contributing $8 \%$ of national coffee production. Humbang Hasundutan Regency has a type of coffee called "Lintong coffee" or Sigarar Utang coffee. The area of coffee plantations in the Regency is about 9,246 ha and with production of 6,461 tons. Coffee plantations consist of $48.45 \%$ of agricultural and plantation land area (Humbahas in 2011). In Humbang area, there are also several other varieties such as Onan Ganjang, Jember and Lasuna, but the production of these three varieties have been very small at only $5 \%$.

However, the level of coffee productivity in Indonesia is still relatively lower, which is $700 \mathrm{~kg} / \mathrm{ha}$. The productivity in North Sumatra is above the national average, $1,022 \mathrm{~kg} / \mathrm{ha} /$ year, occupying the second position after Aceh with a productivity of $1,158 \mathrm{~kg} / \mathrm{ha} /$ year. However, at the local level, the productivity of Arabica coffee in Humbang Hasundutan Regency is still low at $867.35 \mathrm{~kg} / \mathrm{ha} /$ year. This production is still far from the potential of similar Arabica coffee production which can reach 1.50 - 2.0 tons / ha / year (Disbun Province of North Sumatra, 2013).

This study was aimed to obtain the maximum potential of coffee production at a certain height in Humbahas Regency with a package treatment of pruning, fertilizing and shade technology.

\section{METHODS OF RESEARCH}

The study were carried out at an elevation zone of 1300-1400 meters above sea level ( $\mathrm{m}$ asl) which was designed in the form of Splits plot design. Experiments was carried out for 1 year. There are three factors were tested, the main plot is shade with a level without shade (N0) and shade (N1); subplots are pruning, namely pruning with the farmer system (P1) and recommended pruning (P2); while the subplots are fertilization, consisting of: farmers' fertilizing dose (O0), organic fertilizer from coffee pulp at a dose of $10 \mathrm{~kg} /$ tree (O1), organic fertilizer from manure at a dose of $10 \mathrm{~kg} /$ tree (O2), phosphate fertilizer (SP36) $150 \mathrm{~g} /$ tree. This observation was carried out using 10 sample plants from each sample plot and each sample plot was repeated three times. The parameters of growth and production of coffee plants observed were: 1) number of productive branches, 2) number of bunches / branches, 3) number of fruit / bunches, 4) total fruit / trees, 5) diameter of canopy, 6) wet weight of coffee beans, and 7) dry water content of $14 \%$.

$$
\begin{gathered}
Y_{i j k}=\mu+K_{l}+A_{i}+Y_{i l}+B_{j}+(A B)_{i j}+\delta_{i j l}+C_{k}+(A C)_{i k}+(B C)_{j k}+(A B C)_{i j k}+\varepsilon_{i j k l} \\
i=1,2 \ldots, a ; j=1,2 \ldots b ; k=1,2 \ldots c ; l=1,2 \ldots r
\end{gathered}
$$


Where:

$Y_{\mathrm{ijk}}$ : Observation in the first experimental unit that obtained a combination treatment of the $\mathrm{i}-$ level of factor $A$, the $\mathrm{j}$-level of factor $\mathrm{B}$, and the k-level of factor $\mathrm{C}$;

$\mu$ : Population average Value;

$\mathrm{K}_{\mathrm{I}}$ : The effect of additive from group I;

$A_{\mathrm{i}}$ : The effect of additive to i-level from $A$ factor (Main plot);

$\mathrm{Y}_{\mathrm{il}}$ : Random effect of the main plot, which appears at the first level of $A$ factor in the first group;

$B_{j}:$ The effect of additive j-level from $B$ factor (subplot);

$(A B)_{i j}$ : The effect of additive level $A$ factor and the j-level of $B$ factor;

$\delta_{\mathrm{ij}}$ : Random effects from the first experimental unit that obtain an ij treatment combination

(Plot of b errors);

$\mathrm{C}_{\mathrm{k}}$ : Random effects from the first experimental unit that obtain an ij treatment combination (Plot of b error);

$(A C)_{i k}$ : The effect of additive level -i of $A$ factor and k-level of $C$ factor;

(BC)jk: The effect of additive level $\mathrm{j}$ of $\mathrm{B}$ factor and k-level of factor $\mathrm{C}$;

$\varepsilon_{\mathrm{ijk}}$ : Random effects of the first experimental unit that obtain an ijk treatment combination (plot of c errors).

\section{RESULTS AND DISCUSSION}

At an elevation of $1300-1400 \mathrm{~m}$ above sea level, the shading as the main plot only gives a significant effect on dry weight parameters of the seeds (Figure 1). Likewise, pruning and fertilizing as subplots and subplots did not have a significant effect on all parameters (Table 1). The interaction effect which is known to given significant effect is the ShadingPruning-Fertilization, which produces a real effect on all parameters.

Table 1 - Recapitulation results of Analysis Variance in Growth and Production of Arabica Coffee Plants on Shading, Pruning and Fertilizing at elevation 1,300 - 1,400 m above sea level

\begin{tabular}{|c|c|c|c|c|c|c|c|}
\hline \multirow{2}{*}{ Variable } & \multirow{2}{*}{$\begin{array}{c}\text { Shading } \\
(\mathrm{N})\end{array}$} & \multirow{2}{*}{$\begin{array}{c}\text { Pruning } \\
(\mathrm{P})\end{array}$} & \multirow{2}{*}{$\begin{array}{c}\text { fertilization } \\
(\mathrm{O})\end{array}$} & \multicolumn{4}{|c|}{ interaction effect } \\
\hline & & & & NP & $\mathrm{NO}$ & $\mathrm{PO}$ & NPO \\
\hline Canopy Diameter & ns & Ns & Ns & ns & ns & ns & ** \\
\hline Number of Productive Branches & ns & Ns & Ns & $\mathrm{ns}$ & ns & ns & ** \\
\hline Number of fruit bunches & ns & Ns & Ns & ns & ns & ns & ** \\
\hline Number of Fruits / bunches & ns & Ns & Ns & ns & ns & ns & ** \\
\hline Wet Weight of Fruit & ns & Ns & Ns & ns & ns & ns & ** \\
\hline Dry Weight of Fruit & * & Ns & Ns & ns & ns & ns & ** \\
\hline
\end{tabular}

Note: (ns) : not significantly different at LSD test at $5 \%,\left(^{*}\right)$ : significantly different at $L S D$ test at $5 \%$, $\left({ }^{* *}\right)$ : very significantly different on $L S D$ test $1 \%$.

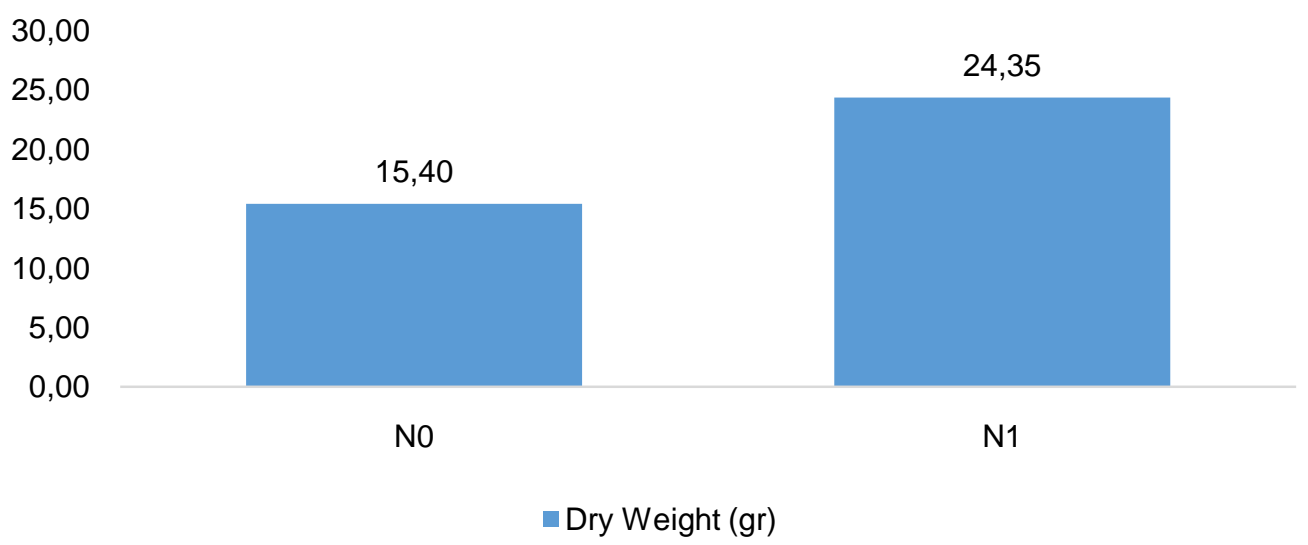

Figure 1 - Weight of Dry Arabica Coffee Beans in Shaded and Unshaded Conditions, in Humbahas Regency, North Sumatra Province 
Litter produced from the coffee shade is a source of organic matter and a source of carbon for the life of organisms in the soil. Soil organisms play a role in the carbon cycle and soil nutrients, improve soil structure and granulation and food web interactions. Soil organisms play a direct or indirect role in soil fertility and productivity (Barrios, 2007). According to Staver, et al (2001), in areas of low elevation or in dry zone areas the intensity of shade use of $35-60 \%$ can reduce the loss of coffee leaves during the dry season and can reduce disease attacks caused by the fungus Cercorspora coffeicola and Planacoccus citri, but can increase Hemileia vastatrix attacks.

Based on Figure 1, the presence of shade in Arabica coffee plantations can affect the yield (fruit weight). These results are in line with those presented by Bote and Struik (2011), where Arabica coffee plants that use shade produce greater seed weight $(148 \mathrm{~g} / 1000$ seeds) than those without shade (134 g / 1000 seeds) and better seed quality than without shade. Different results obtained by Cerda, et al. (2016), where the shade of coffee plants in the agroforestry system in Costa Rica has no effect on coffee production. However, it was found that coffee production in shaded conditions was more stable over a long time.

This result is due to the fact that shade trees can affect the microclimate in coffee plants and shade trees can reduce temperatures to below the optimal range. Coffee plants without shade will increase the absorption of carbohydrates from the leaves and stems to accelerate the formation of fruit and flowers, resulting in damaged roots and leaves (molt). According to Camargo (2010), for Arabica coffee the average annual temperature range is optimal from 18 to $23^{\circ} \mathrm{C}$. Temperatures above $23^{\circ} \mathrm{C}$, cause the development and maturation of fruit to be accelerated, often causing a decrease in quality. Continuous exposure to daily temperatures as high as $30^{\circ} \mathrm{C}$ can produce not only depressed growth but also abnormalities such as leaf yellowing (Damatta and Ramalho, 2006). Using the shade can maintain coffee yields for a long time. In addition, the shade slows the ripening of the coffee fruit and produces larger beans with good coffee quality (Muschler, 2001).

Table 2 - Effect interaction of Shade, Pruning and Fertilization on Growth and Production of Arabica Coffee Plants at elevation 1,300 - 1,400 m asl

\begin{tabular}{ccccccc}
\hline \multirow{2}{*}{ Treatment Combination } & \multicolumn{5}{c}{ Variable } \\
\cline { 2 - 6 } & JCP & DKnp & JTd & JBh td & BBsh & BKr \\
\hline $\mathrm{N}_{0} \mathrm{P}_{1} \mathrm{O}_{0}$ & $20.67 \mathrm{ba}$ & $170.0 \mathrm{ba}$ & $14.0 \mathrm{~b}$ & $16.3 \mathrm{e}$ & $79.4 \mathrm{ba}$ & $14.8 \mathrm{c}$ \\
$\mathrm{N}_{0} \mathrm{P}_{1} \mathrm{O}_{1}$ & $16.00 \mathrm{~b}$ & $170.0 \mathrm{ba}$ & $12.0 \mathrm{~b}$ & $26.0 \mathrm{~d}$ & $81.1 \mathrm{ba}$ & $11.2 \mathrm{c}$ \\
$\mathrm{N}_{0} \mathrm{P}_{1} \mathrm{O}_{2}$ & $13.33 \mathrm{a}$ & $186.7 \mathrm{ba}$ & $8.7 \mathrm{~b}$ & $18.0 \mathrm{e}$ & $49.6 \mathrm{~b}$ & $10.2 \mathrm{c}$ \\
$\mathrm{N}_{0} \mathrm{P}_{1} \mathrm{O}_{3}$ & $16.67 \mathrm{~b}$ & $165.0 \mathrm{ba}$ & $12.0 \mathrm{~b}$ & $21.7 \mathrm{~d}$ & $84.9 \mathrm{ba}$ & $18.9 \mathrm{~b}$ \\
$\mathrm{~N}_{0} \mathrm{P}_{2} \mathrm{O}_{0}$ & $28.67 \mathrm{a}$ & $158.3 \mathrm{~b}$ & $15.7 \mathrm{~b}$ & $27.0 \mathrm{~d}$ & $72.0 \mathrm{ba}$ & $12.7 \mathrm{c}$ \\
$\mathrm{N}_{0} \mathrm{P}_{2} \mathrm{O}_{1}$ & $16.00 \mathrm{~b}$ & $175.0 \mathrm{ba}$ & $17.3 \mathrm{~b}$ & $30.3 \mathrm{c}$ & $85.3 \mathrm{ba}$ & $25.2 \mathrm{ba}$ \\
$\mathrm{N}_{0} \mathrm{P}_{2} \mathrm{O}_{2}$ & $22.33 \mathrm{ba}$ & $166.7 \mathrm{ba}$ & $19.0 \mathrm{~b}$ & $34.7 \mathrm{c}$ & $72.7 \mathrm{ba}$ & $15.7 \mathrm{c}$ \\
$\mathrm{N}_{0} \mathrm{P}_{2} \mathrm{O}_{3}$ & $14.67 \mathrm{~b}$ & $171.7 \mathrm{ba}$ & $19.0 \mathrm{~b}$ & $30.7 \mathrm{c}$ & $71.4 \mathrm{ba}$ & $14.5 \mathrm{c}$ \\
$\mathrm{N}_{1} \mathrm{P}_{1} \mathrm{O}_{0}$ & $15.67 \mathrm{~b}$ & $211.7 \mathrm{~b}$ & $25.7 \mathrm{ba}$ & $25.3 \mathrm{~d}$ & $125.2 \mathrm{a}$ & $32.5 \mathrm{a}$ \\
$\mathrm{N}_{1} \mathrm{P}_{1} \mathrm{O}_{1}$ & $10.67 \mathrm{c}$ & $203.3 \mathrm{a}$ & $32.3 \mathrm{a}$ & $39.0 \mathrm{~b}$ & $76.4 \mathrm{ba}$ & $21.3 \mathrm{~b}$ \\
$\mathrm{~N}_{1} \mathrm{P}_{1} \mathrm{O}_{2}$ & $17.33 \mathrm{~b}$ & $186.7 \mathrm{ba}$ & $30.3 \mathrm{a}$ & $32.3 \mathrm{c}$ & $63.1 \mathrm{ba}$ & $17.9 \mathrm{~b}$ \\
$\mathrm{~N}_{1} \mathrm{P}_{1} \mathrm{O}_{3}$ & $9.00 \mathrm{c}$ & $196.7 \mathrm{ba}$ & $35.7 \mathrm{a}$ & $60.3 \mathrm{a}$ & $64.3 \mathrm{ba}$ & $21.1 \mathrm{~b}$ \\
$\mathrm{~N}_{1} \mathrm{P}_{2} \mathrm{O}_{0}$ & $10.67 \mathrm{c}$ & $196.7 \mathrm{ba}$ & $23.7 \mathrm{ba}$ & $38.7 \mathrm{~b}$ & $57.4 \mathrm{ba}$ & $20.2 \mathrm{~b}$ \\
$\mathrm{~N}_{1} \mathrm{P}_{2} \mathrm{O}_{1}$ & $15.00 \mathrm{~b}$ & $191.7 \mathrm{ba}$ & $16.7 \mathrm{~b}$ & $45.7 \mathrm{a}$ & $77.9 \mathrm{ba}$ & $20.2 \mathrm{~b}$ \\
$\mathrm{~N}_{1} \mathrm{P}_{2} \mathrm{O}_{2}$ & $12.67 \mathrm{c}$ & $216.7 \mathrm{a}$ & $36.3 \mathrm{a}$ & $54.7 \mathrm{a}$ & $83.4 \mathrm{ba}$ & $39.1 \mathrm{a}$ \\
$\mathrm{N}_{1} \mathrm{P}_{2} \mathrm{O}_{3}$ & $14.67 \mathrm{~b}$ & $201.7 \mathrm{ba}$ & $30.0 \mathrm{a}$ & $70.0 \mathrm{a}$ & $75.2 \mathrm{ba}$ & $22.4 \mathrm{~b}$ \\
\hline
\end{tabular}

Note: The numbers followed by different letter notations in the same column are significantly different in the LSD test at 5\%. $J C P=$ number of productive branches / plants; DKnp = diameter of the plant canopy; JTd = number of fruit bunches / plants; $J B h=$ number of fruit / bunch; BBsh = wet weight of fruit ; Bkr = dry weight of truit (moisture content 12\%).

The best effect of shade interaction, pruning and fertilizing for the number of productive branches was obtained at $\mathrm{N}_{0} \mathrm{P}_{2} \mathrm{O}_{0}$ (non shading, recommended pruning and fertilizer dosage for farmers), as many as 22.33 branches. Whereas the lowest productive branch growth was obtained in $\mathrm{N}_{1} \mathrm{P}_{1} \mathrm{O}_{3}$ (with shading, pruning with farmers' system and applying SP36 $150 \mathrm{~g} /$ tree) of 9 branches. These results are in accordance with the nature of the growth of coffee plants that are not shaded by multiplying branches. 
In the parameters of canopy diameter, the best influence of shading, pruning and fertilizing interaction was obtained at $\mathrm{N}_{1} \mathrm{P}_{2} \mathrm{O}_{2}$ (non shading, recommended pruning and fertilizing with $10 \mathrm{~kg} /$ manure fertilizer) with a canopy diameter of $216.7 \mathrm{~cm}$, while the smallest canopy diameter was at $\mathrm{N}_{0} \mathrm{P}_{2} \mathrm{O}_{0}$ (non shading, recommended pruning and fertilizer application at farmer's dose) of $158.3 \mathrm{~cm}$.

In the parameters of the number of bunches / trees, the best influence of shading, pruning and fertilizing interaction is obtained at $\mathrm{N}_{1} \mathrm{P}_{2} \mathrm{O}_{2}$ (with shading, recommended pruning and $10 \mathrm{~kg} /$ manure fertilizer) and $\mathrm{N}_{1} \mathrm{P}_{1} \mathrm{O}_{3}$ (with shading, pruned system of farmers and SP36 $150 \mathrm{~g} /$ tree fertilizer) with the number of bunches 36.3 and 35.7 pieces, while the number of bunches at least in $\mathrm{N}_{0} \mathrm{P}_{1} \mathrm{O}_{2}$ (non shading, pruning of farmer system and fertilizing with manure $10 \mathrm{~kg} /$ tree) as many as 8.7 bunches/tree.

In the parameters of the number of fruit / bunches / trees, the best influence of shade, pruning and fertilizing interactions was obtained at $\mathrm{N}_{1} \mathrm{P}_{2} \mathrm{O}_{3}$ (with shading, recommended pruning and SP36 fertilizer dosage of $150 \mathrm{~g} /$ tree) with the number of fruit 70 fruits / bunches, while the least number of fruits was at $\mathrm{N}_{0} \mathrm{P}_{1} \mathrm{O}_{0}$ (non shading, farmers' pruning and fertilizing systems at a farmer's dose) of 16.3 fruits / bunches / trees.

In the wet seed weight parameters, the best influence of shade, pruning and fertilizing interaction was obtained at $\mathrm{N}_{1} \mathrm{P}_{1} \mathrm{O}_{0}$ (with shading, farmer system pruning and farmer dose fertilizer) with wet seed weight $125.2 \mathrm{~g}$, while the lowest wet seed weight at $\mathrm{N}_{0} \mathrm{P}_{1} \mathrm{O}_{2}$ (non shading, pruning system of farmers and fertilizers with manure $10 \mathrm{~kg} /$ tree) weighing $49.6 \mathrm{~g}$.

In the dry seed weight parameters, the best influence of shade, pruning and fertilizing interaction was obtained at $\mathrm{N}_{1} \mathrm{P}_{2} \mathrm{O}_{2}$ (with shading, recommended pruning and manure $10 \mathrm{~kg}$ / tree) with dry seed weight $39.1 \mathrm{~g}$, while the lowest dry seed weight was at $\mathrm{N}_{0} \mathrm{P}_{1} \mathrm{O}_{2}$ (non shading, pruning system of farmers and fertilizing with manure $10 \mathrm{~kg} /$ tree) weighing $10.2 \mathrm{~g}$. Likewise, when viewed from the percentage of heavy shrinkage from wet-dry, the best interaction was found in $\mathrm{N}_{1} \mathrm{P}_{2} \mathrm{O}_{2}$ (with shading, recommended pruning and $10 \mathrm{~kg} /$ manure fertilizer), with a shrinkage of $53 \%$. This depreciation value is much lower compared to $\mathrm{N}_{0} \mathrm{P}_{1} \mathrm{O}_{0}$ (non shading, pruning the farmer system and fertilizing at farmer dosage) with a wet seed weight of $125.2 \mathrm{~g}$ and experiencing a shrinkage of $74 \%(32.5 \mathrm{~g})$ in the dry weight of the seed. This is identical to the vegetative growth process in that the flowering and fruiting process of coffee is influenced by the amount and distribution of sunlight that can be absorbed by plants. In coffee plants with high light intensity will cause greater energy loss than those used for photosynthesis. The reduced yield of photosynthesis will also reduce the growth and development of coffee plants including fruit formation. The light entering under the shade can be utilized as optimal as possible for the process of flowering and fruiting of coffee plants.

The intensity of sunlight that is too high and not evenly distributed will disrupt the process of growth and development of plants towards the process of flowering and fruiting. Geromel, et al. (2008) suggested that the activity of sucrose and sucrose-phosphate synthesis was higher in shade-grown coffee plants than those without shade (full sunlight). The negative effects of extremely strong sunlight can damage enzymes due to photooxidation. This disrupts the metabolism of organisms, especially the ability to synthesize proteins. This mechanism is very much related to the decrease in micro air temperature in the shade coffee. Boreux et.al (2013) states that the main effects of shade on coffee plants provide a decrease in air temperature fluctuations by $2-3^{\circ} \mathrm{C}$, reduce wind speed, and increase the relative humidity of the air. Decreasing wind speed is very important to prevent flower fall.

\section{CONCLUSION}

The shading as the main plot only gives a significant effect on dry weight parameters of the seeds. However, the interaction effect which is known to given significant effect is the Shading-Pruning-Fertilization, which produces a real effect on all parameters. In the zone of elevation zones 1300-1400 $\mathrm{m}$ asl the combination of shading, recommended pruning and 10 $\mathrm{kg} /$ tree manure (N1P2O2) is the best treatment. 


\section{REFERENCES}

1. Barrios, E. 2007. Soil biota, ecosystem services and land productivity. Ecological Economics. 64:269-285.

2. BPS. 2011. Humbahas Dalam Angka (Humbahas in Numbers), Badan Pusat Statistik Kab Humbang Hasundutan, Sumatera Utara. [Indonesian]

3. Beer J., R. Muschler, D. Kass and E. Somarriba, 1998. Shade management in coffee and cacao plantations, Agroforestry Systems 38: 139-164, Kluwer Academic Publishers. Printed in the Netherlands.

4. Bilir N, Prescher F, Ayan S, Lindgren D. 2006. Growth characters and number of strobili in clonal seed orchards of Pinus sylvestris. Euphytica 152(2):293-301.

5. Boreux, V., Kushalappa, C.G., Vaast, P., Ghazoul, J., 2013. Interactive effects among ecosystem services and management practices on crop production: pollination in coffee agroforestry systems. Proc. Natl. Acad. Sci. U. S. A. 110, 8387-8392.

6. Camargo, M.B.P. 2010. The impact of climatic variability and climate change on Arabic coffee crop in Brazil. Bragantia 69: 239-247.

7. Cerda. R., C. Allinne, C. Gary, P. Tixier, A. H. Celia, K. Louise, M. Charlie, E. Clément, A. Jean-Noel and J. Avelino. 2016. Effects of shade, altitude and management on multiple ecosystem services in coffee agroecosystems. Europ. J. Agronomy. 82(2017): 308 - 319. http://dx.doi.org/10.1016/j.eja. 2016.09.019

8. Dariah, A.; F. Agus and Maswar (2005). Kualitas tanah pada lahan usahatani berbasis tanaman kopi (Studi Kasus di Sumber Jaya, Lampung Barat). Jurnal Tanah and Iklim, 23, $48-57$.

9. Da Matta, F.M., and J.D.C Ramalho. 2006. Impacts of drought and temperature stress on coffee physiology and production: a review, 18(1): 55-81.

10. DaMatta, F.M. 2004. Ecophysiological constraints on the production of shaded and unshaded coffee, Field Crops Research 86: 99-114.

11. Dishutbun, 2013. Laporan Tahunan Bidang Perkebunan Tahun, 2013. Dinas Kehutanan and Perkebunan Kab. Humbang Hasundutan, Sumatera Utara.

12. Dossa, E.L., Fernandez, E.C.M., Reid, W.S., Ezui, K., 2008. Above-and below ground biomass, nutrient and carbon stocks contrasting an open-grown and a shaded coffee plantation. Agrofor. Syst. 72, 103-115.

13. Dutkuner I, Bilir N, Ulusan MD. 2008. Influence of growth on reproductive traits and its effect on fertility and gene diversity in a clonal seed orchard of scots pine. J. Env. Biol. 29:349-352.

14. [GAEKI]. Gabungan Eksportir Kopi Indonesia. 2015. Area and Produksi. [internet]. [diunduh 2018 maret 01] tersedia pada: http://gaeki.or.id/areal-dan-produksi/.

15. Geromel, C., L.P. Ferreira, F. Davrieux, B. Guyot, F. Ribeyre, M. B. D. Scholz, F. P. P. Luiz, P. Vaast, Pot D. T. Leroy, A. Androcioli, L. G. E. Vieira, P. Mazzafera, P. Marraccini. 2008. Effects of shade on the development and sugar metabolism ofcoffee (Coffea arabica L.) fruits. Plant Physiol. Biochem. 46: 569 - 579.

16. Hairiah, K. \& S. Rahayu (2010). Mitigasi perubahan iklim (Agroforestri kopi untuk mempertahankan cadangan karbon lanskap). Prosiding Simposium Kopi, Denpasar, Indonesia.

17. [ICO] International Coffee Organization. 2009. Opportunities and challenges for the world coffee sector, Multi-stakeholder Consultation on Coffee of the Secretary- General of UNCTAD, Geneva: International Coffee Organisation.

18. ICO, 2014. International Coffee Organization statistical database ICO. (accessed 20.1.2019) http://www.ico.org.

19. Marsh, Antony. 2005. A review of Aceh coffee industry. UNDP ERTR Livelihood Component.

20. Mawardi, S., Yusianto, R. Hulupi, Khalid, and A. Marsh. 2008. Evaluasi Citarasa Beberapa Varietas Kopi Arabika pada Ketinggian Tempat and Cara Pengolahan yang Berbeda di Dataran Tinggi Gayo (NAD). Workshop Forum Kopi Aceh. Takengon, 25 Oktober 2008. 
21. Muschler, R. G. 2001. Shade improves coffee quality in a sub-optimal coffee zone of Costa Rica. Agrofor. Syst. 85: 131 - 139.

22. Panggabean, E. 2011. Buku Pintar Kopi. Agromedia Pustaka. Jakarta. $226 \mathrm{hlm}$.

23. Prawoto, A., A. M. Nur, S. W. A. Soebagiyo, and M. Zaubin. 2006. Uji alelopati beberapa spesies tanaman penaung terhadap bibit kopi arabika (Coffea arabica L.). Pelita Perkebunan 22 (1): 1-12.

24. Roldán-Pérez, Adriana; Maria-Alejandra Gonzalez-Perez, Pham Thu Huong, and Dao Ngoc Tien (2009). Coffee, cooperation and competition: A comparative study of Colombia and Vietnam, UNCTAD Virtual Institute. http://www.vi.unctad.org/resourcesmainmenu-64/digital-library?coffee.

25. Staver, C., F. Guharay, D. Monterroso and R. Muschler. 2001. Designingpestsuppressive multistrata perennial crop systems: shade-grown coffee in Central America. Agrofor. Syst. 53: $151-170$.

26. Wintgens, J.N., 2012. In: 2nd, revised edition (Ed.), Coffee: Growing, Processing, Sustainable Production - A Guidebook for Growers, Processors, Traders, and Researchers. Wiley, Weinheim. http://dx.doi.org/10.1002/9783527619627. 